\title{
Aktivitas Antiinflamasi Ekstrak Etanol Echinometra mathaei pada Tikus Putih Jantan dengan Induksi Karaginan
}

\section{The Anti-inflamation activity of Ethanolic Extract of Echinometra mathaei on White Male Rat with Carrageenan Induced Paw Oedema}

\author{
Angelica Kresnamurti ${ }^{1 *}$, Hardiyono ${ }^{1}$, Febriana Siswulandari ${ }^{1}$, Iwan Sahrial Hamid ${ }^{2}$ \\ ${ }^{I}$ Prodi Farmasi, Fakultas Kedokteran, Universitas Hang Tuah Surabaya \\ ${ }^{2}$ Departemen Farmakologi, Fakultas Kedokteran Hewan, Universitas Airlangga Surabaya \\ *Correspondence author: angelica.kresnamurti@hangtuah.ac.id
}

Received: 29 Juni 2021; Accepted: 18 Oktober 2021; Published: 31 Desember 2021

\begin{abstract}
Abstrak
Bulu babi (Echinometra mathaei) merupakan salah satu biota laut yang mengandung senyawa flavonoid dan fenolik yang tinggi, berpotensi sebagai antiinflamasi dan antioksidan. Penelitian ini bertujuan untuk mengukur aktivitas antiinflamasi ekstrak etanol $70 \%$ Bulu Babi pada tikus putih jantan yang diinduksi karaginan. Uji aktivitas antiinflamasi menggunakan 5 kelompok tikus yang dipilih secara acak, setiap kelompok terdiri dari 5 ekor tikus. Kelompok kontrol negatif, kontrol positif, dan 3 kelompok Ekstrak (dosis 100, 200, dan 400mg/kgBB). Masingmasing kelompok diinduksi menggunakan karaginan $1 \%$ secara subplantar dan volume edema diukur menggunakan plethysmometer air raksa setiap 30 menit selama 3 jam. Data dianalisis secara statistik menggunakan Anava satu arah. Hasil penelitian menunjukkan bahwa persentase hambatan inflamasi kelompok kontrol positif, dan kelompok ekstrak etanol Echinometra mathaei (dosis 100, 200, dan $400 \mathrm{mg} / \mathrm{KgBB}$ ) menunjukkan perbedaan bermakna $(\mathrm{P}<0,05)$ dengan kelompok kontrol negatif dengan nilai persentase hambatan inflamasi berturut-turut sebesar $61,11 \%, 85,19 \%, 85,19 \%$, dan $74,07 \%$. Pemberian ekstrak etanol bulu babi pada semua dosis mempunyai persentase antiinflamasi yang lebih tinggi dari natrium diklofenak, tetapi peningkatan dosis ekstrak tidak memberikan peningkatan hambatan inflamasi yang bermakna. Kesimpulan penelitian ini adalah Ekstrak etanol 70\% Echinometra mathaei pada dosis 100, 200, 400 $\mathrm{mg} / \mathrm{KgBB}$ memiliki potensi aktivitas antiinflamasi yang kuat
\end{abstract}

Kata Kunci : Antiinflamasi, Echinometra mathaei, Ekstrak Etanol, Karaginan, Pletysmometer, Natrium Diklofenak

Abstract

Sea urchin (Echinometra mathaei) is one of the marine biota that contains high flavonoid and phenolic compounds that are potent as anti-inflammatory and antioxidant. This study aimed to measure the anti-inflammatory activity of the $70 \%$ ethanol extract of sea urchins in male white rats induced by carrageenan. Anti-inflammatory activity test using 5 groups of rats selected randomly, each group consists of 5 rats. Negative control group, positive control group, and 3 groups of extracts (doses of 100, 200, and 400mg/kgBW). Each group was induced using 1\% carrageenan subplantarly and the volume of edema was measured using a mercury plethysmometer every 30 minutes for 3 hours. The data were statistically analyzed using one-way Anova. The results showed that the percentage of inflammatory inhibition in the positive control group, and the Echinometra mathaei ethanol extract group (dose of $100,200$, and $400 \mathrm{mg} / \mathrm{KgBW})$ showed a significant difference $(P<0.05)$ with the negative control group with a percentage value of Inflammation inhibition was $61.11 \%, 85.19 \%, 85.19 \%$, and $74.07 \%$, respectively. The administration of sea urchin ethanol extract at all doses had a higher percentage of anti-inflammatory than diclofenac sodium, but increasing the extract dose did not significant increase inflammatory inhibition. This research concluded that $70 \%$ ethanol extract of Echinometra mathaei at doses of 100,200, $400 \mathrm{mg} / \mathrm{KgBW}$ has strong anti-inflammatory activity potential.

Keywords: Anti-inflammatory, Echinometra mathaei, Ethanol Extract, Carrageenan, Pletysmometer, Diclofenac Sodium 


\section{PENDAHULUAN}

Bulu babi atau dikenal dengan nama lokal landak laut, tayum, tehe-tehe adalah salah satu jenis benthos (filum Echinodermata, kelas Echinoidea) yang memiliki bentuk bulat dan ditutupi dengan duri panjang bergerak (Rahim, et al., 2016). Bulu babi berperan sebagai indikator dalam pengendalian pertumbuhan vegetasi di laut, karena makanan utama bulu babi adalah rumput laut dan mikroalga bentik (Pinna et al., 2012). Bulu babi adalah hewan yang aktif di malam hari untuk mencari makan, sedangkan siang hari akan bersembunyi pada celah karang (Soleimani et al., 2016 ${ }^{\mathrm{a}}$ ).

Bulu babi memiliki cangkang yang keras dan bagian dalamnya berisi gonad yang mengandung asam amino essensial, $\beta$-carotene dan dochosahecaenat acid (DHA) (Dincer et al., 2007). Pada analisis gonad Diadema Setosum menemukan $80 \%$ polyunsaturated fatty acids (PUFA) diantara lainnya eicosapentaenoic acid (EPA), asam arakidonat (AA) dan karotenoid yang mengandung senyawa antioksidan, seperti echinenone, $\beta$ carotene dan fucoxathine (Chen et al., 2010). Kandungan nutrisi yang terdapat pada gonad bulu babi meliputi vitamins A, B9, polyunsaturated fatty acids (PUFA), dan flavonoids, dapat menekan inflamasi kronik (Kim and Lee, 2013).

Stimulus berbahaya bagi tubuh seperti sel rusak, bakteri pathogen, iritan akan menimbulkan kerusakan yang serius apabila tubuh tidak mempunyai respon terjadinya inflamasi. Adanya inflamasi menguntungkan tubuh karena berperan sebagai respon protektif terhadap stimulus-stimulus di atas. Walaupun gejala-gejala inflamasi seperti bengkak, algesia, dan disfungsi jaringan akan menyebabkan rasa tidak nyaman (Egesie et al., 2011; Ehlers and Kaufmann, 2010).

Menurut terjadinya, inflamasi dapat timbul secara akut maupun kronis, dan menimbulkan dampak lokal ataupun sistemis juga menimbulkan kelainan patologis.
Pengobatan utamanya adalah adalah meredakan nyeri dan menghentikan kerusakan jaringan. Obat yang diberikan adalah golongan steroid dan anti inflamasi non steroid (OAINS), tetapi memberikan efek samping serius pada penggunaan dalam jangka panjang, contohnya peningkatan risiko tukak lambung dan perdarahan saluran cerna bagian atas nonvariceal pada penggunaan OAINS (Lanza et al., 2009).

Saat ini telah banyak penelitian yang berasal dari biota laut tentang agen antiinflamasi. Salah satu biota laut yang memiliki potensi sebagai agen antiinflamasi ialah bulu babi. Bulu babi diketahui mempunyai aktivitas sebagai antiinflamasi, antioksidan dan antidiabetes (Soleimani et al., 2016 ${ }^{\mathrm{a}}$ ). Aktivitas antiinflamasi dari ekstrak gonad bulu babi Echinometra mathaei yang diekstraksi dengan metanol menunjukkan aktivitas sebagai antiinflamasi yang tinggi dengan standar aspirin (Soleimani et al., 2016 ${ }^{\mathrm{b}}$ ). Berdasarkan penelitian sebelumnya, ekstrak etanol $70 \%$ Bulu babi yang didapatkan dari Pulau Weh, sabang, NAD ini juga mempunyai efek analgesik yang setara dengan asetosal pada dosis $200 \mathrm{mg} / \mathrm{KgBB}$ (Lestiono dkk, 2020) dan diperkirakan mempunyai mekanisme penghambatan terhadap prostaglandin. Pelarut etanol $70 \%$ dipilih pada penelitian ini karena polaritas lebih baik daripada methanol-air, sehingga diharapkan lebih banyak senyawa yang tersari dalam ekstrak etanol $70 \%$, selain lebih aman, dan universal untuk pelarut pengekstraksi di industry (Riwanti et al., 2020). Berdasarkan uraian tersebut, maka peneliti ingin mengetahui aktivitas antiinflamasi dari ekstrak etanol $70 \%$ bulu babi (Echinometra mathaei) terhadap tikus putih jantan galur wistar (Rattus norvegicus L.) yang diinduksi karaginan.

\section{METODE PENELITIAN}

Penelitian ini bersifat true experimental (dimana dilakukan penelitian dengan 
randomisasi sampel, terdapat kelompok kontrol dan perlakuan) dengan menggunakan pre testpost test control grup design, dimana volume kaki tikus diamati sebelum dan setelah diberikan perlakuan.

\section{Alat Penelitian}

Alat yang digunakan antara lain adalah alat-alat ekstraksi meliputi : gelas (Pyrex), timbangan analitik (Ohauss), oven (Memmert), IKA-Rotary evaporator RV-10, mortir dan stampher, timbangan digital, pipet, corong buchner, dan alat-alat pengujian pada tikus meliputi : spuit, Plethysmometer air raksa, kertas perkamen, sendok tanduk.

\section{Bahan Penelitian}

Bahan uji yang digunakan adalah gonad dan cangkang dari Echinometra mathaei yang dikoleksi dari pulau Weh kota sabang, Nanggroe Aceh Darussalam dan dideterminasi pada UL Biologi FST-Unair pada Agustus 2019. Echinometra mathaei yang didapatkan dari laut Pulau Weh, Sabang-Aceh telah disortasi, dikeringkan, dan ekstraksi secara maserasi dengan etanol $70 \%$.

Bahan kimia yang digunakan adalah natrium diklofenak (tablet generik, Novell) sebagai pembanding, kappa karaginan 1\% (teknis, Brataco), aquadest, dan CMC Na (teknis, Brataco) sebagai suspending agent. Pada penelitian ini Natrium diklofenak digunakan sebagai kontrol positif karena natrium diklofenak mempunyai efek antiinflamasi dengan waktu puncak yang sangat pendek, sesuai jenis induksi edema yang digunakan (karaginan 1\%).

\section{Hewan Coba dan Pertimbangan Etik}

25 ekor tikus putih jantan, galur wistar, berat badan berkisar antara 150-250 gram, usia 2-3 bulan. Tikus dibagi menjadi 5 kelompok secara acak dan setiap kelompok adalah 5 ekor tikus. Populasi hewan coba dipastikan dalam keadaan sehat dan tidak ada kelainan yang tampak pada bagian tubuhnya terutama bagian kaki. Tikus diadaptasikan dahulu pada lingkungan laboratorium selama 7 hari sebelum digunakan untuk penelitian pada suhu ruang \pm $25^{\circ} \mathrm{C}, 12$ jam terang dan 12 jam gelap. Makanan standar dan minum diberikan ad libitum. Kandang yang digunakan adalah single cage dengan ukuran 41 x 31 x $13 \mathrm{~cm}$ dengan sekam sebagai alas dalam kandang. Penelitian ini telah lolos uji etik penelitian kesehatan dengan sertifikat KEPK FKG Universitas Hang Tuah nomor : Sket/041/KEPK-FKGUHT/XI/2019.

\section{Uji aktivitas antiinflamasi}

Sebanyak 25 ekor tikus digunakan dalam penelitian ini berdasarkan rumus Federer dengan 5 jenis kelompok uji, setiap kelompok terdiri dari 5 ekor tikus. Perhitungan rumus Federer berdasarkan rumus $[(\mathrm{t}-1)(\mathrm{n} 1)=15]$ dimana $t$ adalah jumlah perlakuan yang diberikan dan $\mathrm{n}$ adalah jumlah sampel tiap kelompok yang digunakan (Widiyatno dan Muniroh, 2018).

Sebelum perlakuan semua kelompok tikus diukur volume kakinya. Semua kelompok tikus diberikan induksi karaginan 1\%, secara subplantar dan segera diberikan perlakuan dengan sediaan uji secara per oral berturut-turut adalah kelompok I (CMC Na 5\%) sebagai kontrol negatif, kelompok II (Natrium diklofenak $5 \mathrm{mg} / \mathrm{KgBB}$ ) sebagai kontrol positif, kelompok III, IV, dan V diberikan ekstrak berturut-turut dengan dosis 100, 200, dan 400 $\mathrm{mg} / \mathrm{KgBB}$. Pemilihan dosis berdasarkan efektivitas ekstrak Echinometra mathaei pada penelitian analgesik (Lestiono dkk, 2020) dan antipiretik sebelumnya (Kresnamurti et al., $\left.2021^{\mathrm{a}}\right)$.

Percobaan ini menggunakan metode induksi karaginan, dengan pemberian induksi karaginan $1 \%$ kepada tikus yang akan menimbulkan edema pada kaki. Volume edema yang muncul setelah diinduksi diukur setiap 30 menit selama 3 jam, sesuai hasil orientasi dimana puncak edema setelah 3 jam, setelahnya 
edema akan berkurang walaupun tdk diberikan obat, dan kembali normal setelah 24 jam.

Perhitungan volume edema dihitung dengan rumus $\mathrm{Vu}=\mathrm{Vtn}-\mathrm{Vn}$, dimana $\mathrm{Vu}$ adalah Volume edema ( $\mathrm{ml})$, Vtn adalah Volume edema kaki tikus pada waktu ke-n (ml), dan Vn adalah Volume kaki normal tikus (ml). Volume edema diakumulasikan dan dihitung presentase hambatan inflamasi untuk setiap kelompok. Perhitungan persen edema dengan rumus:

$$
\% \text { edema }=\frac{V_{t-V_{n}}}{V_{n}} \times 100 \%
$$

(Pramitaningastuti dan Anggraeny, 2017)

\section{Analisis statistik}

Data jumlah kumulatif volume edema tikus masing-masing kelompok, dianalisis dengan SPSS versi 22.0 secara statistik parametrik, one way anova dan dilanjutkan dengan LSD untuk mengetahui apakah terdapat perbedaan antar kelompok hewan coba.

\section{HASIL DAN PEMBAHASAN}

Hasil rendemen yang diperoleh dari proses ekstraksi dengan cara maserasi adalah sebesar 20,95\% dengan berat ekstrak sebesar $104,78 \pm 3,56 \mathrm{~g}$. Maserasi dilakukan dengan 3 kali perendaman selama 3 x 24 jam kemudian dilakukan evaporasi dengan rotavapour sehingga didapatkan ekstrak kental.

Proses perjalanan inflamasi atau terbentuknya edema diukur menggunakan pletismometer air raksa. Pengukuran volume kaki semua tikus, dilakukan sebelum induksi dan sesudah perlakuan pada semua tikus dari setiap kelompok.

Pada tabel 1, terlihat bahwa pemberian natrium diklofenak, dan ekstrak bulu babi memberikan penurunan rerata volume edema kaki tikus yang telah diinduksi karaginan. Penurunan yang signifikan terdapat pada kelompok ekstrak etanol $70 \%$ Echinometra mathaei $100 \mathrm{mg} / \mathrm{kgBB}$ dan $200 \mathrm{mg} / \mathrm{kgBB}$ yang memiliki rerata efek penurunan edema yang sama dan paling besar penurunan presentase volume edemanya dibandingkan pemberian Natrium diklofenak $5 \mathrm{mg} / \mathrm{kgBB}$ dan ekstrak bulu babi dosis $400 \mathrm{mg} / \mathrm{KgBB}$.

Pada penelitian ini, peningkatan dosis tidak sejalan dengan peningkatan efek anti inflamasi dari ekstrak. Hal ini serupa dengan penelitian sebelumnya dimana dosis yang lebih besar tidak menunjukkan peningkatan efek (Lestiono, dkk, 2020; Kresnamurti, et al, $2021^{\mathrm{b}}$ ). Berdasarkan penelitian Lestiono ditemukan bahwa dosis $200 \mathrm{mg} / \mathrm{KgBB}$ mempunyai aktivitas analgetika yang lebih tinggi daripada dosis 100 dan $400 \mathrm{mg} / \mathrm{KgBB}$ (Lestiono, dkk, 2020). Penelitian dengan ekstrak Bulu babi dari Sabang ini juga dilakukan untuk uji hepatoprotektor pada tikus, didapatkan bahwa dosis ekstrak 800 mg/KgBB lebih baik daripada dosis ekstrak 400 dan 1200 $\mathrm{mg} / \mathrm{KgBB}$ (Kresnamurti, et al., 2021 ${ }^{\mathrm{b}}$ ).

Tabel 1. Rerata Persentase Peningkatan Vol Edema Kaki Tikus Tiap Satuan Waktu (menit)

\begin{tabular}{ccccccccc}
\hline \multirow{2}{*}{ Perlakuan } & \multicolumn{6}{c}{ Rerata \% edema tiap satuan menit } & \multicolumn{2}{c}{ edema (\%) } \\
\cline { 2 - 7 } & $\mathbf{0}$ & $\mathbf{3 0}$ & $\mathbf{6 0}$ & $\mathbf{9 0}$ & $\mathbf{1 2 0}$ & $\mathbf{1 5 0}$ & $\mathbf{1 8 0}$ & \pm SD \\
\hline Kontrol (-) & $150 \%$ & $150 \%$ & $150 \%$ & $150 \%$ & $25 \%$ & $25 \%$ & $25 \%$ & $96,43 \pm 66,81^{\mathrm{b}}$ \\
Kontrol (+) & $100 \%$ & $87,5 \%$ & $50 \%$ & $25 \%$ & 0 & 0 & 0 & $37,50 \pm 42,70^{\mathrm{a}}$ \\
E100 $\mathrm{mg} / \mathrm{kgbb}$ & $100 \%$ & 0 & 0 & 0 & 0 & 0 & 0 & $14,28 \pm 37,79^{\mathrm{a}, \mathrm{b}}$ \\
E200 $\mathrm{mg} / \mathrm{kgbb}$ & $100 \%$ & 0 & 0 & 0 & 0 & 0 & 0 & $14,28 \pm 37,79^{\mathrm{a}, \mathrm{b}}$ \\
E400 mg/kgbb & $100 \%$ & $25 \%$ & $25 \%$ & $25 \%$ & 0 & 0 & 0 & $25,00 \pm 35,35^{\mathrm{a}}$ \\
\hline
\end{tabular}


Pada penelitian ini yang digunakan adalah ekstrak, sehingga diprediksikan kandungan di dalam ekstrak yang terdiri dari bermacam-macam metabolit sekunder, dapat menghambat senyawa bioaktif yang berperan terhadap aktivitas antiinflamasi, apabila dosis ditingkatkan. Pada dosis yang rendah, kandungan bioaktif yang berperan terhadap aktivitas antiinflamasi, dapat teradsorpsi dengan baik dan bekerja optimal. Hal ini juga tampak pada onset of action dari dosis 100 dan $200 \mathrm{mg} / \mathrm{KgBB}$ lebih cepat daripada dosis 400 $\mathrm{mg} / \mathrm{KgBB}$.

Karaginan dipilih sebagai inflamatogen karena bersifat iritan yang dapat menginduksi peradangan akut pada hewan uji tanpa menyebabkan kerusakan pada kaki hewan uji (Necas and Bartosikova, 2013). Mekanisme karaginan menimbulkan peradangan akut terdiri dari 2 tahap. Tahap pertama timbul pelepasan histamin, serotonin, dan bradikinin, dilanjutkan dengan pelepasan prostaglandin pada tahap kedua, 2-3 jam setelahnya. Penyuntikan karaginan secara sub-plantar pada kaki tikus menyebabkan perkembangan edema dengan puncak edema pada jam ke-4 setelah penyuntikan (Patil and Patil, 2017).

Tabel 2. Persentase Hambatan Inflamasi Tiap Kelompok

\begin{tabular}{cc}
\hline Kelompok & $\begin{array}{c}\text { \% Hambatan } \\
\text { Inflamasi }\end{array}$ \\
\hline Kontrol Negatif & $0 \%$ \\
Kontrol Positif & $61,11 \%$ \\
Ekstrak Bulu Babi 100 mg/Kg BB & $85,19 \%$ \\
Ekstrak Bulu Babi 200 mg/Kg BB & $85,19 \%$ \\
Ekstrak Bulu Babi 400 mg/Kg BB & $74,07 \%$ \\
\hline
\end{tabular}

Hasil penelitian pada tabel 2., terlihat bahwa penghambatan inflamasi oleh ekstrak etanol $70 \%$ bulu babi pada semua dosis lebih tinggi daripada Natrium diklofenak. Menurut Soleimani et al. $\left(2016^{\mathrm{a}}\right)$, ekstrak etil asetat bulu babi Echinometra mathaei mempunyai efek antiinflamasi yang tinggi, yang diperkirakan karena mengandung komponen fenolik dan flavonoid. Flavonoid berperan sebagai antiinflamasi dengan cara menghambat aktivitas siklooksigenase dan lipooksigenase dalam biosintesis jalur inflamasi (Rathee et al., 2009). Hal ini juga tampak pada ekstrak etanol Bulu babi pada penelitian ini yang juga mengandung flavonoid, berdasarkan penelitian skrining fitokimia sebelumnya (Lestiono dkk, 2020).

Pada hasil penelitian tabel 1 , terlihat bahwa onset of action ekstrak pada dosis 100 dan $200 \mathrm{mg} / \mathrm{kgBB}$ lebih cepat daripada natrium diklofenak yaitu kurang dari 30 menit, dan efek hambatan inflamasi yang tinggi mencapai $100 \%$. Onset of action dan efek hambatan edema lebih cepat dan lebih tinggi dibandingkan pemberian Natrium diklofenak yaitu setelah 90 menit dan $75 \%$. Natrium diklofenak memiliki waktu paruh yang cukup singkat yaitu selama 2 jam dengan waktu puncak 0,5 - 1,5 jam setelah pemberian (Altman et al., 2015) sehingga harus diberikan dalam beberapa dosis perhari. Natrium diklofenak juga terikat pada protein plasma sebesar $97 \%$ dan diakumulasi di cairan sinovial setelah pemberian pada hewan coba (Miyatake et al., 2008).

Hasil uji statistik menunjukkan pemberian dosis ekstrak 100 dan 200 mg/KgBB menunjukkan perbedaan yang signifikan $(\mathrm{P}<0,05)$ dibandingkan dengan pemberian CMC-Na (kontrol negatif) dan pemberian Natrium diklofenak (kontrol positif). Pemberian ekstrak etanol $70 \%$ Echinometra mathaei mempunyai aktivitas antiinflamasi dengan mula kerja yang lebih baik dan aktivita antiinflamasi yang lebih tinggi daripada pemberian natrium diklofenak. Ekstrak etanol 70\% Bulu Babi (Echinometra mathaei) yang diperoleh dari sabang, NAD, mempunyai aktivitas antiinflamasi yang kuat, karena mempunyai persen hambatan yang lebih tinggi daripada Natrium diklofenak yang tergolong 
antiinflamasi kuat, sehingga berpotensi untuk dikembangkan lebih lanjut.

\section{KESIMPULAN}

Berdasarkan hasil penelitian dapat disimpulkan bahwa Ekstrak etanol $70 \%$ Echinometra mathaei pada dosis 100, 200, $400 \mathrm{mg} / \mathrm{KgBB}$ memiliki potensi aktivitas antiinflamasi yang lebih tinggi dari natrium diklofenak.

\section{UCAPAN TERIMAKASIH}

Ucapan terimakasih diberikan kepada LPPM Universitas Hang Tuah Surabaya atas pembiayaan penelitian berdasarkan hibah penelitian dosen internal periode 2019-2020.

\section{Daftar Pustaka}

Altman, R., Bosch, B., Brune, K., Patrignani, P., and Young, C., 2015, Advances in NSAID Development: Evolution of Diclofenac Products Using Pharmaceutical Technology Drugs, 75:859-877.

Chen, G., Weng, Z. X., Chi, C. L., Juang, P., Jian, W. Q., Feng, C., Yue, J., 2010, A comparative analysis of lipid and carotenoid composition of the gonads of Anthocidaris crassispina, Diadema setosum and Salmacis sphaeroides. Food chemistry, 120 (4): p. 973-977.

Dincer, T. and Cakli, S., 2007, Chemical composition and biometrical measurements of the Turkish Sea urchin (Paracentrotus lividus, Lamarck, 1816). Critical Reviews in Food Science and Nutrition, 47(1): 21-26.

Egesie U.G., Chima K.E., dan Galam N.Z., 2011, Anti-inflammatory and Analgesic Effects of Aqueous Extract of Aloe Vera (Aloe barbadensis) in Rats. Afr. J. Biomed., 209-212.

Ehlers S, Kaufmann S., 2010, Infection, inflammation, and chronic diseases: consequences of a modern lifestyle. Trends Immunol, 31:184-90.

Hutauruk, T., Rosita, A., Oktavianawati, I., 2014, Sintesis Asam 2-(2-(n-(2,6-diklorofenil)-4 fluorobenzamida)fenil)asetat sebagai Kandidat Obat Penghambat COX (siklooksigenase). Ejurnal Pustaka Kesehatan. Vol 2(02):215-220.

Kim W dan Lee H., 2013, Advances in nutritional research on regulatory T-cells. Nutrients., 5(11):4305-15.

Kresnamurti, A., Hardiyono, Prandana, A.M., 2021a, Evaluation of Antypiretic Activity of Echinometra mathaei from Sabang Nanggoe Aceh Darussalam. International Journal of Advanced Chemistry Research. 3(2):1-3.

Kresnamurti A., Rakhma D.N., Damayanti A., Santoso, S.D., Restryarto, E., Hadinata, W., Hamid, I.S., 2021b, AST/ALT Levels, MDA, and Liver Histopathology of Echinometra mathaei Ethanol Extract on Paracetamol-Induced Hepatotoxicity in Rats. Journal of Basic and Clinical Physiology and Pharmacology. 32(4):511-516.

Lanza FL, Chan FK, Quigley EM., 2009, Guidelines for prevention of NSAID-related ulcer complications. Am J Gastroenterol. 104:728-738.

Lestiono, Kresnamurti, A., Rahmat, E., Ansyori, M.R., 2020, Aktivitas Analgesik Ekstrak Etanol 
Bulu babi pada Mencit Putih Jantan. Herclips (Journal of Herbal, Clinical, and Pharmaceutical Sciences). 01(2).

Miyatake, S., Ichiyama, H., Kondo, E dan Yasuda, K., 2008, Randomized clinical comparisons of diclofenac concentration in the soft tissues and blood plasma between topical and oral applications. British Journal of Clinical Pharmacology.

Necas, J. dan Bartosikova, L., 2013, 'Carrageenan : a review, Veterinarni Medicina. pp. 187-205.

Patil K.R., Patil C.R., 2017, Anti-inflammatory activity of bartogenic acid containing fraction of fruits of Barringtonia racemosa Roxb. in acute and chronic animal models of inflammation. Journal of Traditional and Complementary Medicine. 7. 86-93.

Pinna,S., Pais,A., Campus,P., Sechi,N., dan Ceccherelli., 2012, Habitat Preferences of the Sea Urchin Paracentrotus lividus. Marine Ecology Progress Series. Vol. 445: 173-180.

Pramitaningastuti, A.S. dan Anggraeny E.N., 2017. Uji efektivitas antinflamasi ekstrak etanol daun srikaya (Annona suamosa L.) terhadap edema kaki tikus putih jantan galur wistar. Jurnal Ilmiah Farmasi. Vol 13(01):8-14

Rahim,S. A. K. Ab and Nurhasan, R., 2016, Status of Sea Urchin Resources in the East Coast of Borneo, Journal of Marine Biology Research.

Rathee, P., Chaudhary, H., Rathee, S., Rathee, D., Kumar, V., dan Kohli, K., 2009, Mechanism of Action of Flavonoids as Anti-inflammatory Agents: A Review. PDM College of Pharmacy, Bahadurgarh, India. Inflammation \& Allergy - Drug Targets, Vol. 8, No. 3 229-235.

Riwanti, P., Izazi, F., Amaliyah, 2020, Pengaruh perbedaan konsentrasi etanol 50, 70, 96\% Sargassum polysystum dari Madura. Journal of Pharmaceutical Care Anwar Medika. Vol 02(02):82-95

Soleimani, S., Moein, S., Yousefzadi, M., Bioki, N.A. 2016a. Determination of In Vitro Antioxidant Properties, Anti-inflammatory Effects and A-Amylase Inhibition of Purple Sea Urchin Extract of Echinometra Mathaei from the Persian Gulf. Jundishapur J Nat Pharm.

Soleimani, S., Moein, S., Yousefzadi, M., Bioki, N.A., Rezadoost, H., 2016b, Identification and antioxidant of polyhydroxylated naphthoquinone pigments from sea urchin pigments of Echinometra mathaei. Med Chem Res.; 25:1476-1483.

Widiyatno Y., Muniroh, L., 2018, Dampak pemberian minyak goreng mengandung residu plastic isopropyl terhadap blood urea nitrogen kreatinin tikus putih galur Wistar. Agroveteriner. 07(01). 